Bangladesh J. Bot. 49(2): 313-327, 2020 (June)

\title{
AGRO-PHYSIOLOGICAL ASSESSMENT OF WEED INTERFERENCE IN GROUNDNUT (ARACHIS HYPOGEA L.) AT SUB-HIMALAYAN HILL REGION OF MEGHALAYA
}

\author{
Santosh KoraV*, Vishram Ram, R KrishnapPa ${ }^{1}$ and N Premaradhya \\ School of Natural Resource Management, College of PG-Studies, \\ Umiam-793103, Meghalaya, India
}

Keywords: Agro-physiological assessment, Weed interference, Groundnut

\begin{abstract}
Field experiment was carried out during Kharif and Rabi seasons of 2016-17 at the mid altitudes of Meghalaya in the precincts of Sub Himalayan hill region to assess and quantify the extent of weed interference on growth and physiology of groundnut in both seasons of the year. Crop physiological parameters viz., LAI, CGR, RGR, NAR, SPAD value, leaf thickness, specific leaf area, specific leaf weight and partitioning efficiency which are key for determining growth and yield of crop were documented periodically. The highest values of all the physiological attributes were found in weed free check, and lowest with weedy check. As weeds, biological agents with similar cellular and plant structure equally affect the crop in all sectors of growth and reproduction but it is not shared uniformly across all stages of crop growth but with increasing period of weed interference decrease the extent of damage to crop plants.
\end{abstract}

\section{Introduction}

Groundnut (Arachis hypogea L.) is a leading oilseed crop in India gaining unprecedented importance due to its low photosensitivity, indeterminate growth habit, mid season drought tolerance and wide adaptability in most of the agroclimatic situations. Uniqueness of this crop is its growth of vegetative and reproductive organs overlaps due to inter-organ competition for photo-assimilation and other metabolites which causes low fruiting/pod set efficiency hence affecting yield in unpredictable way (Pushp and Virender 2012). Groundnut is grown extensively under rainfed situation and under non-rainfed conditions. With available irrigation facility this crop can be grown in all the three seasons. In similar way, in receipt of 2 to $10-12$ thousand millimetres of annual rainfall in sub Himalayan region, with ample of sunshine hours available throughout the year, it can be grown in kharif, Rabi and summer seasons of Meghalaya. But there are noticeable changes in productivity across the growth seasons as mostly the yield of Rabi season is lower compared to Kharif due to less occurrence of base temperature. Meagre availability of optimum photothermal indexing causes less growth and consequently affect number of peg formation as well as remarkably increases the length of growing period.

Besides, this season variation of growth and productivity of the crop, unwarranted exposure of the ground crop to myriad of biotic and abiotic factors during active growth stages of crop growth are equally responsible for low productivity of groundnut as their primary effect canopy growth, physiological efficiency and important peg formation stage. Considering biotic factors, weeds being unwanted plants with curse are key agents of innate crop damage because they are capable to reduce the yield of crop till 45 to $60-70 \%$ in the potential arable area of sub-Himalayan regions of Meghalaya with profuse growth, propensity and diversity of weeds. Groundnut, being initially slows growing crop (Senthil et al. 2004), bearing short plant height and underground pod

*Author for correspondence: <santoshkorav@gmail.com>. 'Scientist, ICAR RC for NEH region, Umiam, Meghalaya, India. 
forming habit which provides congenial space and environment for abundant weed growth. The computational stresses of weeds cause substantial yield losses $(15-75 \%)$ depending on the season (Jat et al. 2011). Some common and noticeable weeds with their relative abundance are, Galinsoga parviflora (25\%), Cynodon dactylon 28\%, Eleucine indica (24\%), Ageratum conyzoides (9\%), Euphorbia geniculata (8\%), Amaranthus lividus (6\%) which predominately found in groundnut fields of hill agriculture. Weeds are more prominent in Kharif season due to timely and equal distribution of south-west monsoon which bless higher amount of rain fall with moderate to sufficient conducive growth temperature $\left(18\right.$ to $\left.30^{\circ} \mathrm{C}\right)$ for mesophytes. But in Rabi season, low base temperatures as well as absence or erratic distribution of rain fall affect the growth and plants population in great extent.

Higher weed populations in particular crop growing area significantly effect on growth and development of crop. The physiological and morphological attributes which determine the competitive ability of crops and weeds in terms of capture, explore and exploitation of available resources are utmost important for maximising and out-performing the crop fitness over weed (Swanton et al. 2015). Less weed population, lower biomass and canopy spread with minimum dry weight provides ample space for expression of genetic potential of crop in terms of optimum root growth and proliferation, nodulation, non-stressful expansion of shoot architecture and phenology of plant (Jayarama 1995). The characterisation of physiological parameters and agronomic traits can provide information on the extent of damage by the weed and immensely help in strategically programming the warranted control measures including the optimal timing, type of farm implement and duration of weed stress free period to farmers and land managers. At global level, impact of weeds causes more than $\$ 100$ billion U.S. dollars of economic losses annually (Appleby et al. 2000) and demand around \$25 billion U.S. dollars annual herbicide sales and movement across worldwide (Agrow 2003). For reducing this big dollar's value and environmental pollution with relentless usage of pesticide, greater understanding of crop-weed interactions has become very important and very essential in order to develop cost-effective and sustainable weed management practices to increasing yield. With rational and logical consideration of above facts and figures, present study aimed to evaluate and assess the physiological changes and quantify the impact on yield of ground nut crop in relation with cropweed competition at different growth stages at college experimental unit of Umiam Meghalaya which ideally located at mid altitudes and moderate to heavy rainfall occurring area of subHimalayan region.

\section{Materials and Methods}

Field experiment was conducted at experimental farm of the College of Postgraduate Studies (CAU), Umiam, Meghalaya, India in both Kharif and Rabi seasons of the year 2016 - 2017. The experimental site was located at $091^{\circ} 54.72^{\prime} \mathrm{E}$ longitude and $25^{\circ} 40.886^{\prime} \mathrm{N}$ latitude and an altitude of $950 \mathrm{~m}$ above the mean sea level (MSL). The soil of the experimental site is typical sandy clay loam in texture, soil pH (4.9), organic carbon (0.77\%), NPKS $(282.24,13.04,241.98$, $1.6 \mathrm{~kg} / \mathrm{ha}$ ). The experiment was conducted in a randomized block design, replicated thrice with 12 treatments viz., weeds until 15, 30, 45, 60,75 days after emergence (DAE), weedy treatment and weed free until $15,30,45,60,75$, weed free treatment. ICGS-76 is the variety of test crop i.e groundnut which was suitably sown during two experimental seasons i.e second fortnight of June (23rd June for Kharif) and November (22nd November for Rabi) with plant spacing of $40 \times$ $10 / \mathrm{cm}^{2}$ on flat beds. Recommended doses of N, P and K $25: 60: 60$ NPK kg/ha (Full doses N, P and $\mathrm{K}$ ) were effectively applied at the time of sowing. Other standard agronomic practices were followed during crop growth period and crop was harvested at right time of physiological maturity. Randomly ten plants were selected from each plot and regular biometric observations of 
crop were recorded at appropriate days after emergence (DAE) to harvest with an interval of 15 days.

For leaf area calculation of all the photosynthetically active leaves, five representative plants were selected from each plot by using leaf area meter at 15, 30, 45, 60, 75 days after emergence and the LAI was calculated by using the following formula (Watson 1947).

$$
\text { LAI }=\frac{\text { Leaf area }\left(\mathrm{cm}^{2}\right)}{\text { Ground covering area }\left(\mathrm{cm}^{2}\right)}
$$

The fully expanded matured leaf more specifically, the fifth leaf from the top was used for specific leaf weight (SLW) and specific leaf area (SLA) measurement. Fifth leaf from the top was collected and leaf area was measured using leaf area meter immediately. Later, the leaf was dried in an oven at $60{ }^{\circ} \mathrm{C}$ to constant weight. Weight of the dried leaf was recorded and SLW and SLA were computed using the equation given below.

$$
\text { SLW }=\frac{\text { Leaf weight }}{\text { Leaf area }} \quad \text { SLA }=\frac{\text { Leaf area }}{\text { Leaf weight }}
$$

Leaf thickness was measured using absolute digimetic Vernier calliper (Mitutoyocorp, Japan) with an accuracy of $0.01 \mathrm{~mm}$ and was expressed in $\mathrm{mm}$. This measurement was taken in the broadest part of the matured leaf excluding major veins.

The rate of dry matter production per unit land area per unit time or Crop growth rate (CGR) was worked out by using formula proposed by Watson (1947) and expressed as $\mathrm{g} \mathrm{m}^{-2}$ day $^{-1}$ or $\mathrm{mg}$ day $^{-1} \mathrm{~cm}^{-2}$.

$$
\mathrm{CRG}=\frac{\mathrm{W} 2-\mathrm{W} 1}{\mathrm{t} 2-\mathrm{t} 1} \times \frac{1}{\mathrm{P}}
$$

where, $\mathrm{W} 1$ and $\mathrm{W} 2$ dry matter production $(\mathrm{g})$ per plant at time $\mathrm{t} 1$ and $\mathrm{t} 2$, respectively, $\mathrm{P}=$ Ground area covered by plant $\left(\mathrm{m}^{2}\right)$

The rate of increase in dry weight per unit dry weight expressed in $\mathrm{mg} \mathrm{g}^{-1}$ day $^{-1}$ was calculated using the formula suggested by Blackman (1919).

$$
\mathrm{RGR}=\frac{\log \mathrm{W} 2-\log \mathrm{W} 1}{\mathrm{t} 2-\mathrm{t} 1}
$$

where, W1 and W2 are dry weight production (g) of plant at time $\mathrm{t} 1$ and $\mathrm{t} 2$ respectively. Net assimilation rate (NAR) was determined by the formula given by Beadle (1987) expressed in $\mathrm{mg} \mathrm{cm}{ }^{-2}$ day $^{-1}$.

$$
\mathrm{NAR}=\frac{(\mathrm{W} 2-\mathrm{W} 1)(\log \mathrm{LA} 1-\log \mathrm{LA} 1)}{(\mathrm{t} 2-\mathrm{t} 1)(\mathrm{LA} 2-\mathrm{LA} 1)}
$$

where, $\mathrm{W}_{1}$ and $\mathrm{W}_{2}$ are the dry matter accumulation $(\mathrm{g}), \mathrm{LA} 1$ and LA2 are leaf area $\left(\mathrm{cm}^{2}\right)$ at time $\mathrm{t} 1$ and $\mathrm{t} 2$, respectively.

The chlorophyll content of the plant leaves was recorded at different stages with the help of solvent extraction methods for chlorophyll a, b and total chlorophyll content was also be determined by chlorophyll meter SPAD-502 plus. The observations will be recorded from the five plants in each plot and expressed as Soil Plant Analysis and Development (SPAD index). 
For chlorophyll estimation the third leaves from top was selected as sample and grind with $80 \%$ acetone solution. The required amount was taken and absorbance was measured at 665 and $663 \mathrm{~nm}$ or Spectronic-20 for chlorophyll b, total chlorophyll and chlorophyll a, respectively. Further calculations were done by using the following formulae given by Arnon (1949).

Chl. a $(\mathrm{mg} / \mathrm{g} \mathrm{FW})=(12.72 \times \mathrm{A} 663-2.58 \times \mathrm{A} 645) *(\mathrm{~V} / \mathrm{W}) *(1 / 1000)$

Chl. b $(\mathrm{mg} / \mathrm{g} \mathrm{FW})=(22.87 \times \mathrm{A} 645-4.67 \times \mathrm{A} 663) *(\mathrm{~V} / \mathrm{W}) *(1 / 1000)$

Chl. $\mathrm{a}+\mathrm{b}(\mathrm{mg} / \mathrm{g} \mathrm{FW})=(8.05 \times \mathrm{A} 663+20.29 \times \mathrm{A} 645) *(\mathrm{~V} / \mathrm{W}) *(1 / 1000)$

where $\mathrm{V}$ refers to the total volume of the extract and $\mathrm{W}$ refers to weight of the tissue taken for pigment measurements and A663 and A645 nm is the optical absorbance values recorded by UV2100 at 663 and $645 \mathrm{~nm}$, respectively. FW stands for fresh weight of the tissue.

Partitioning efficiency was calculated as ratio of seed biomass to the total above ground biomass and it can also be expressed in terms of energy content of the seed to the energy content of total above ground biomass at full maturity (Fehr et al. 1971).

The analysis and interpretation of experimental data were performed using the Fisher's method of analysis of variance technique as described by Gomez and Gomez (1984). The level of significance used in ' $F$ ' and ' $\mathrm{t}$ ' test was at $\mathrm{p}=0.05$. Critical difference values were calculated wherever the ' $F$ ' test was significant.

\section{Results and Discussion}

The leaf area index of tested groundnut crop was significantly affected by increasing the length of weed interference period, whereas, on the other hand, it was positively influenced by the increasing span of weed free period. Long weed free treatments obtained higher leaf area, canopy growth and leaf area index (Table 1). However, the lowest was observed in weedy treatment with no weed control measures. The progressive development of leaves follow a definite pattern, further growth and inception of new leaves depending upon the increase in height and development of new branches in the groundnut plant with relation to the length of internodes. As the canopy development of the weeds increasingly restricted the growth and development of the plants, consequently, the foliage coverage of the groundnut was at stake and abridged. Further, it also parallely disturbed the nutrient supply, its allelopathic effect, low water potential and nutrient uptake variation by weeds which resulted in reduced growth and development of leaves as a result lower leaf area index. At later stages of crop growth and leaf senescence that occurs might be another reason of lower leaf area and leaf area index after peak growth stage of 60 days stage. In similar way leaf areas of crop were found to reduce significantly with the increase of the duration of weed competition in rice (Munene et al. 2008).

Weeds were adversely affected on growth attributes of the crop viz., CGR, RGR and NAR during both seasons (Tables 2 - 3 and Figs 1 - 3). The CGR and RGR initially increased up to 45 $60 \mathrm{DAE}$ after that declined progressively up to harvesting in both seasons. CGR was significantly influenced at $45-60 \mathrm{DAE}$ in the treatment of weed free check with 1.33, 0.76 and 1.04 $\mathrm{mg} / \mathrm{day} / \mathrm{cm}$ in Kharif, Rabi and pooled, respectively than the other weed free and weedy treatments. Similarly, RGR was also up to 30 to 45 DAE, reported maximum in Kharif than Rabi, after which the Rabi season dominated CGR in terms of higher values than Kharif up to Harvesting (Figs 1, 2 and 3). During Kharif, maximum RGR was significantly influenced at 30 $45 \mathrm{DAE}$ in weed free check with $0.038 \mathrm{mg}$ g/day and in Rabi season at 45 - 60 DAE in weed free check with $0.031 \mathrm{mg} / \mathrm{g} /$ day (Table 2). The net assimilation rate (NAR) in the plant increased with the progress of the growth period of the groundnut during both the seasons of the experimentations (Table 3). However, NAR of Kharif season was higher than the Rabi seasons irrespective of the 

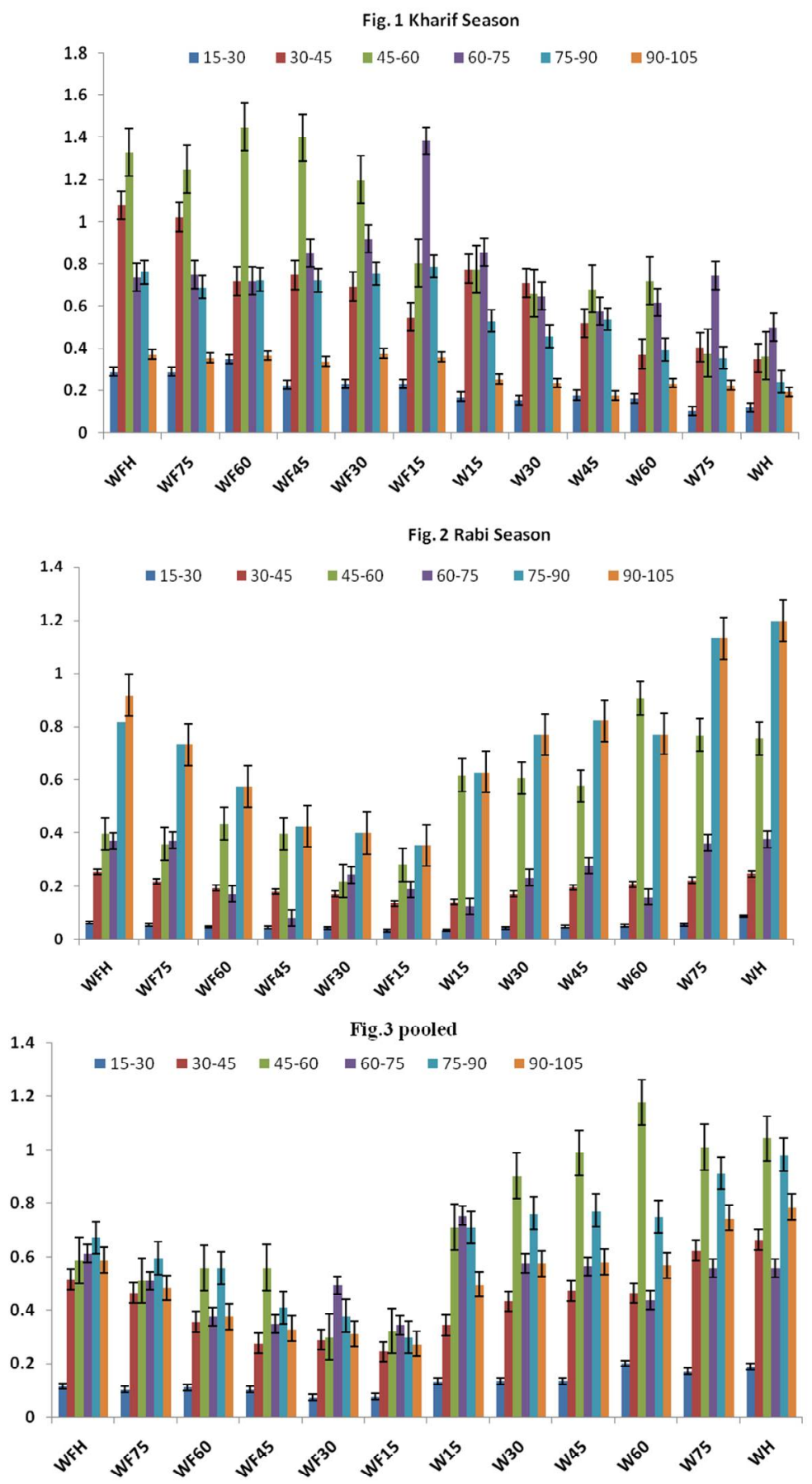

Figs 1- 3: Crop growth rate $\left(\mathrm{mg} / \mathrm{day}^{\prime} \mathrm{cm}^{2}\right)$ of groundnut as influenced periodically by different stages of weedy and weeds free treatments. 


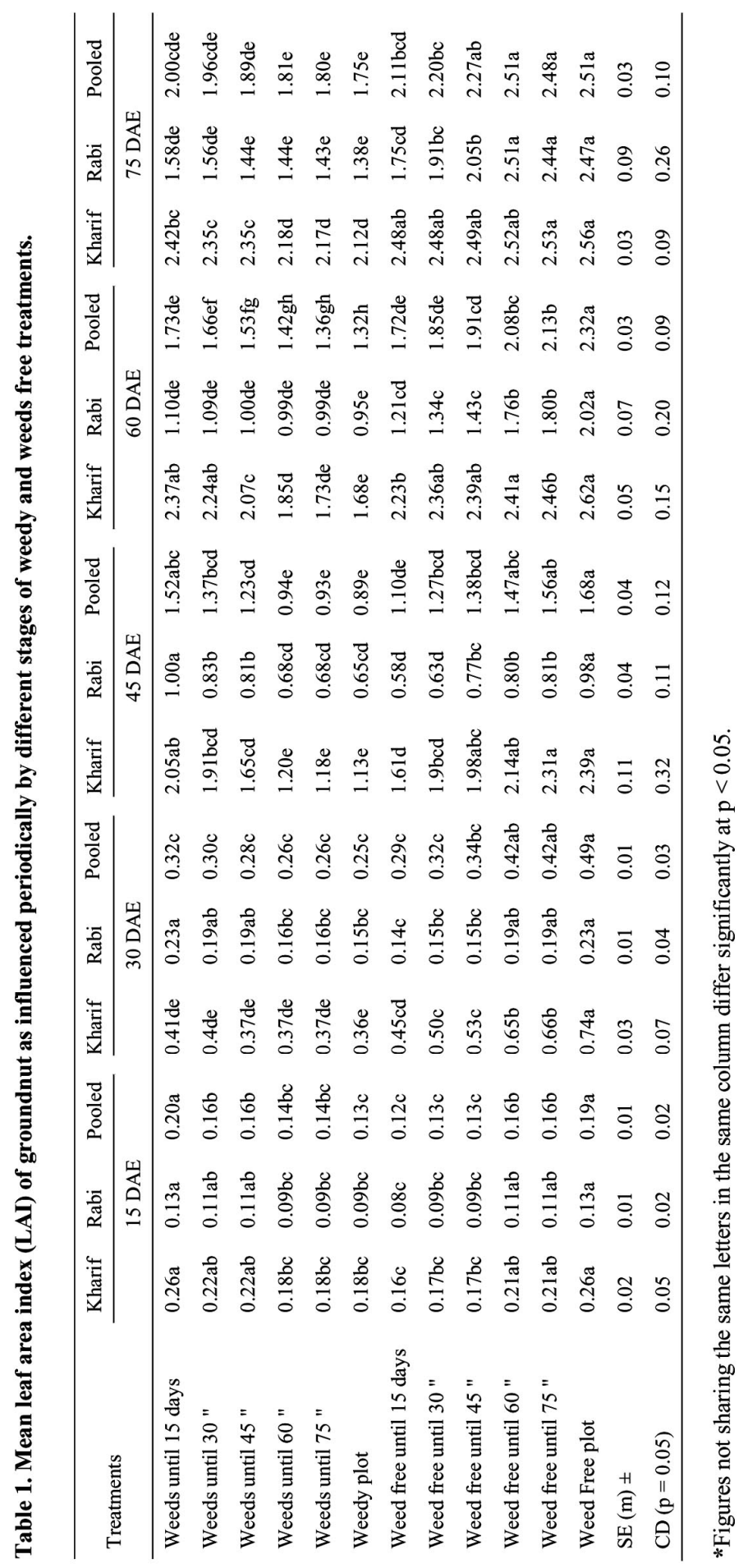




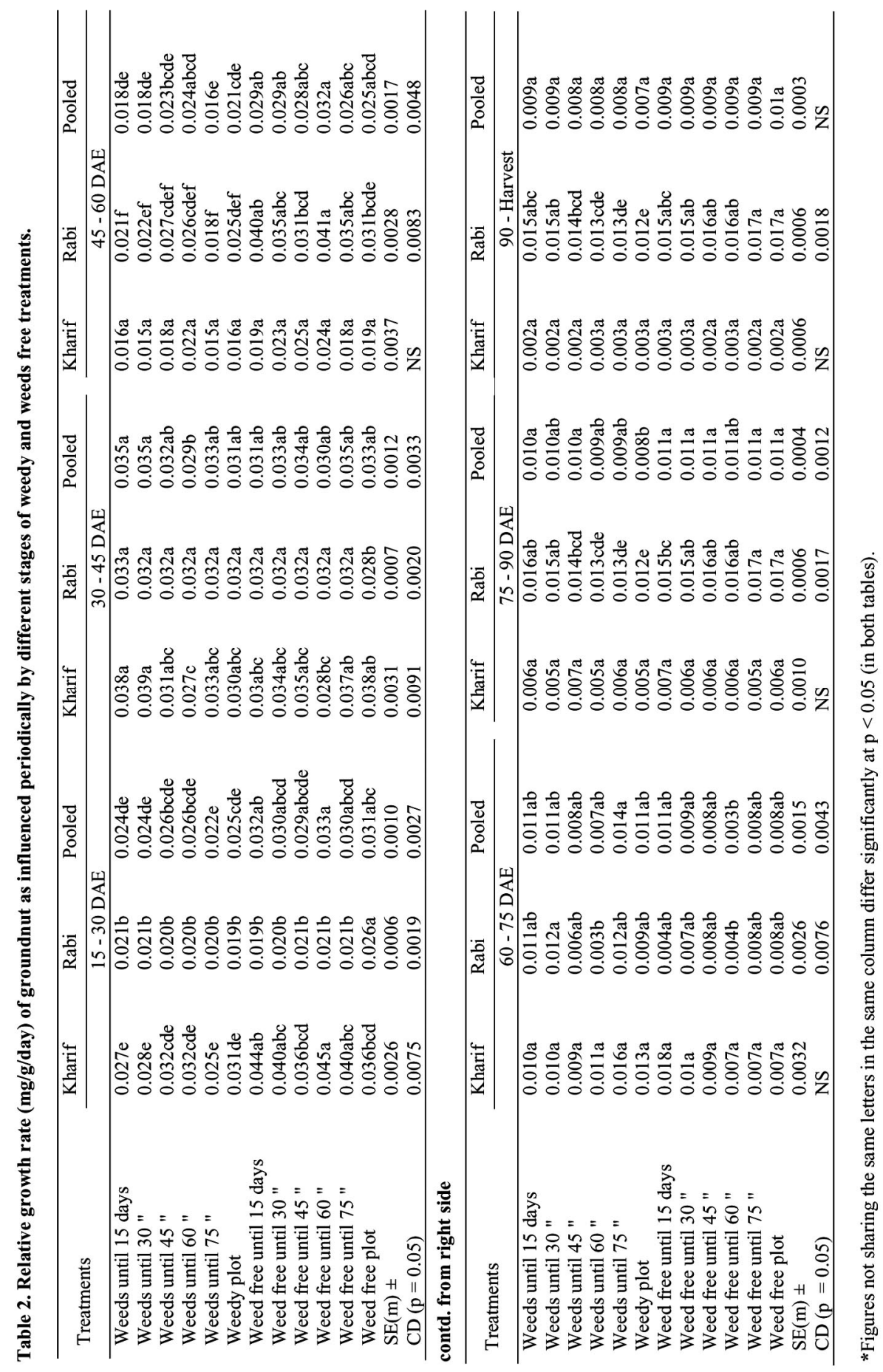


growth stages. Among the different weed free treatments weed free up to 30 to 45 DAE produced higher NAR with $0.33,0.27 \mathrm{mg} \mathrm{cm} /$ day in Kharif and pooled respectively, and $0.21 \mathrm{mg} \mathrm{cm} / \mathrm{day}$ during Rabi season. However, CGR, RGR and NAR initially exhibited increasing trend which reached maximum at active vegetative stage after that decreased gradually up to its harvesting stage. It might be due to CGR and dry matter accumulation from initial to reproductive stage, will be more as compared to later stages. Once crop reached to reproductive stage it started translocations and remobilisation of photosynthetic material from source to sink. This might be due to the declining of the RGR and NAR after achieving grand growth phase in groundnut crop. Similarly, in the present study, at later stages crop was infested with insect cause early leaf shedding and senescence at important physiological growth stages. The similar results were supported by Banik et al. (2009) who reported that decline in RGR towards physiological maturity could be due to leaf shedding, shadow or less light transmittance of upper leaves over the lower leaves which reduce the photosynthetic capacity of the lower leaves and finally loss of leaves due to pest attack in groundnut. However, the weed free treatments accumulated maximum NAR as compared to weedy treatments. Olayinka and Etejere (2015) observed that in two groundnut varieties at peak periods between 8 and 8-10 WAS in MK 373 and Samnut 10, respectively. Highest NAR in weed free plots or plot raised under rice straw mulch + one hand weeding at 6 WAS and lowest NAR was recorded in weedy check.

The chlorophyll content measured using SPAD chlorophyll meter reading (SCMR) was found to decrease with increasing duration of weed interference period during both the seasons of the experimentations. Completely weed free plots accumulated higher SPAD value than the other weed free periods and weedy plots of different intervals in kharif, Rabi and pooled. At 60 days after sowing (DAS) the SCMR value was higher in weed-free check due to higher accumulation and retention of chlorophyll content of leaves in Kharif, Rabi and pooled. Moreover, minimum SCMR was found in the weedy check because weeds utilize higher incident sunlight as compared to crop. It affects leaf chlorophyll content in groundnut. Hakim et al. (2013) reported that the chlorophyll content (SCMR value) was found to decrease with increasing duration of weed interference period. The maximum chlorophyll content (42.10 SCMR) was observed in the long weed-free treatment followed by 75 days weed-free and 30 days weedy treatments (more than 41) while the minimum chlorophyll content was found in the season-long weedy treatments. Leaf chlorophyll is the main pigment and growth factor for healthy photosynthesis in plants. Increase of the weed free period increases the leaf chlorophyll content by increased synthesis or reduced degradation, but the reduction trend increased with increasing the duration of weedy period. It is strongly influenced by environmental factors (Qiu et al. 2007).

Higher leaf thickness was recorded in weeds until 15 DAE during both the seasons individually and in pooled data of experimentation at 45 DAS. Similarly, at 60 DAS higher leaf thickness was recorded at weed free check (Table 4). At 45 days, weeds showed synergistic effect and at 60 days high utilisation of light for their canopy development, numbers of leaves and leaf thickness in weed free treatments, but in weedy treatments minimum leaf thickness was recorded. This is due to increase of weed density which affects plant leaf mesophyll performance.

Different weed regimes show their significant effect on specific leaf area and specific leaf weight (Table 5). During crop growth at 45 days after sowing (DAS) stage, above two parameters were observed maximum in weed affected treatments until 15 DAE but at 60 DAS it was found in season long weed free treatment. Similarly, initial free treatments showed increasing trend and initial weedy treatments were showed deceasing trend. It clearly indicated that, with the increase of crop weed competition, weeds outperforms the crops in utilising the maximum amount of water from different depth of soil through their different and profuse root growth pattern as well as root adaptive mechanisms that influence and uptake to utilises more nutrients, 


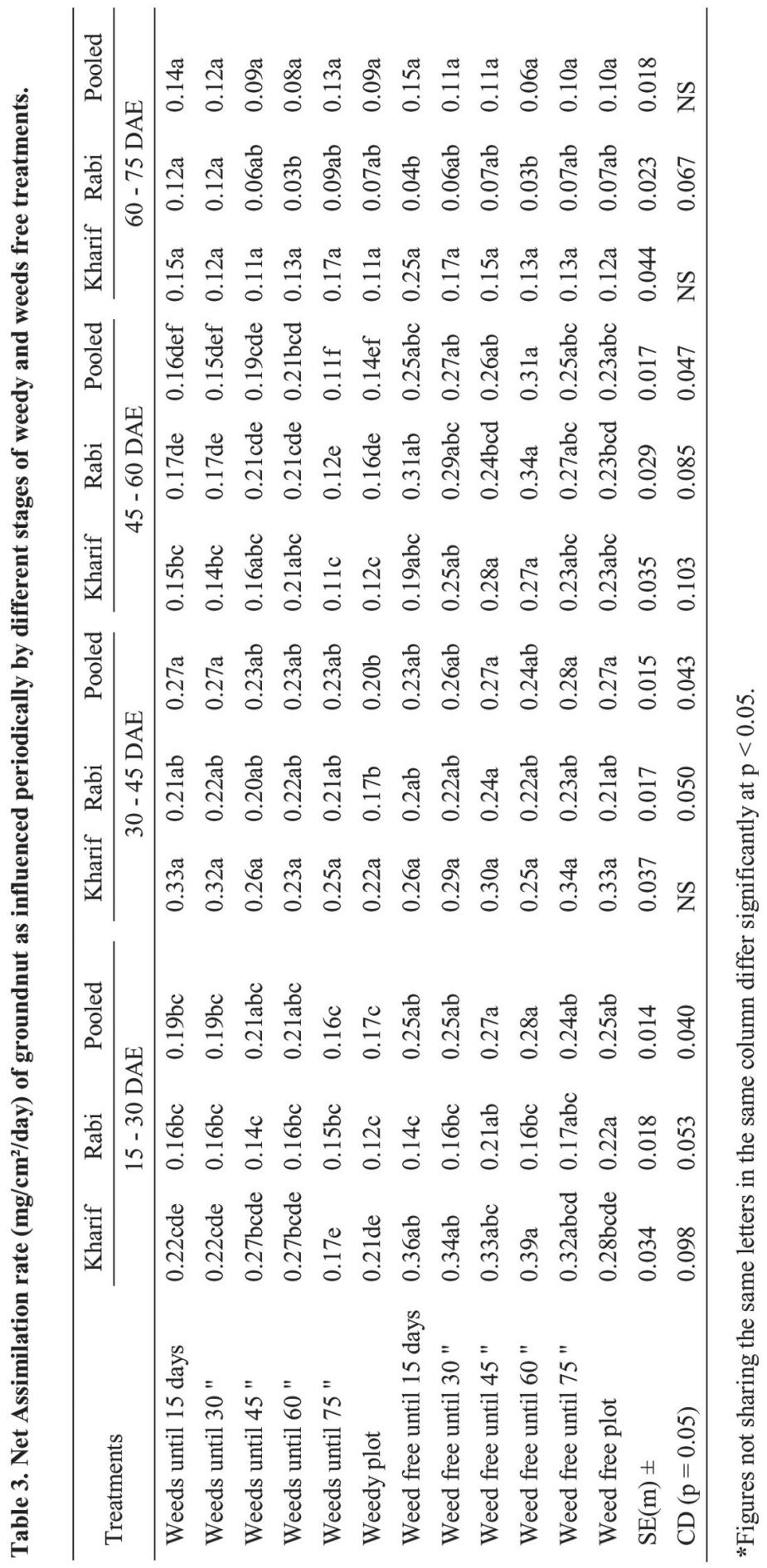




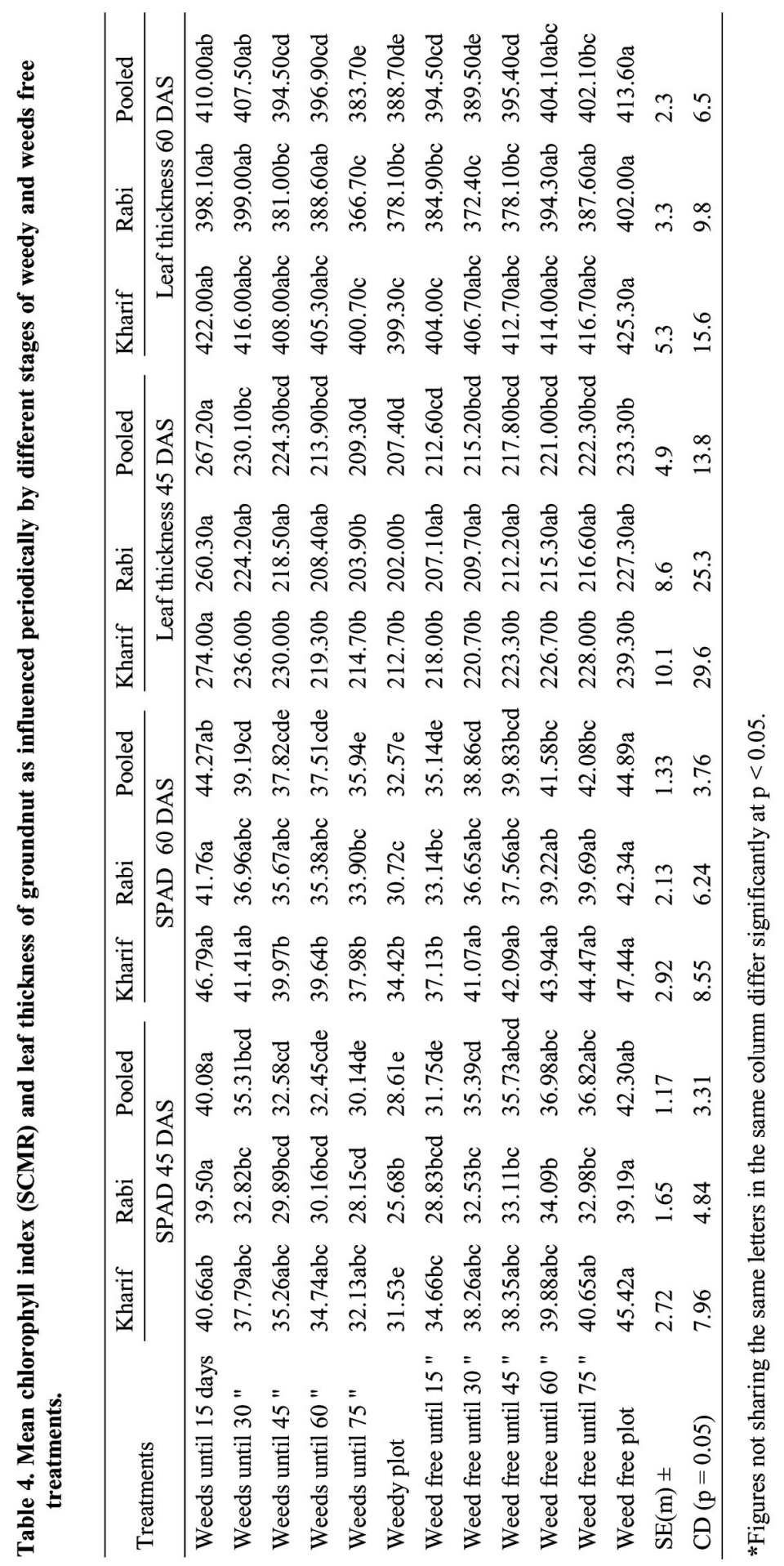




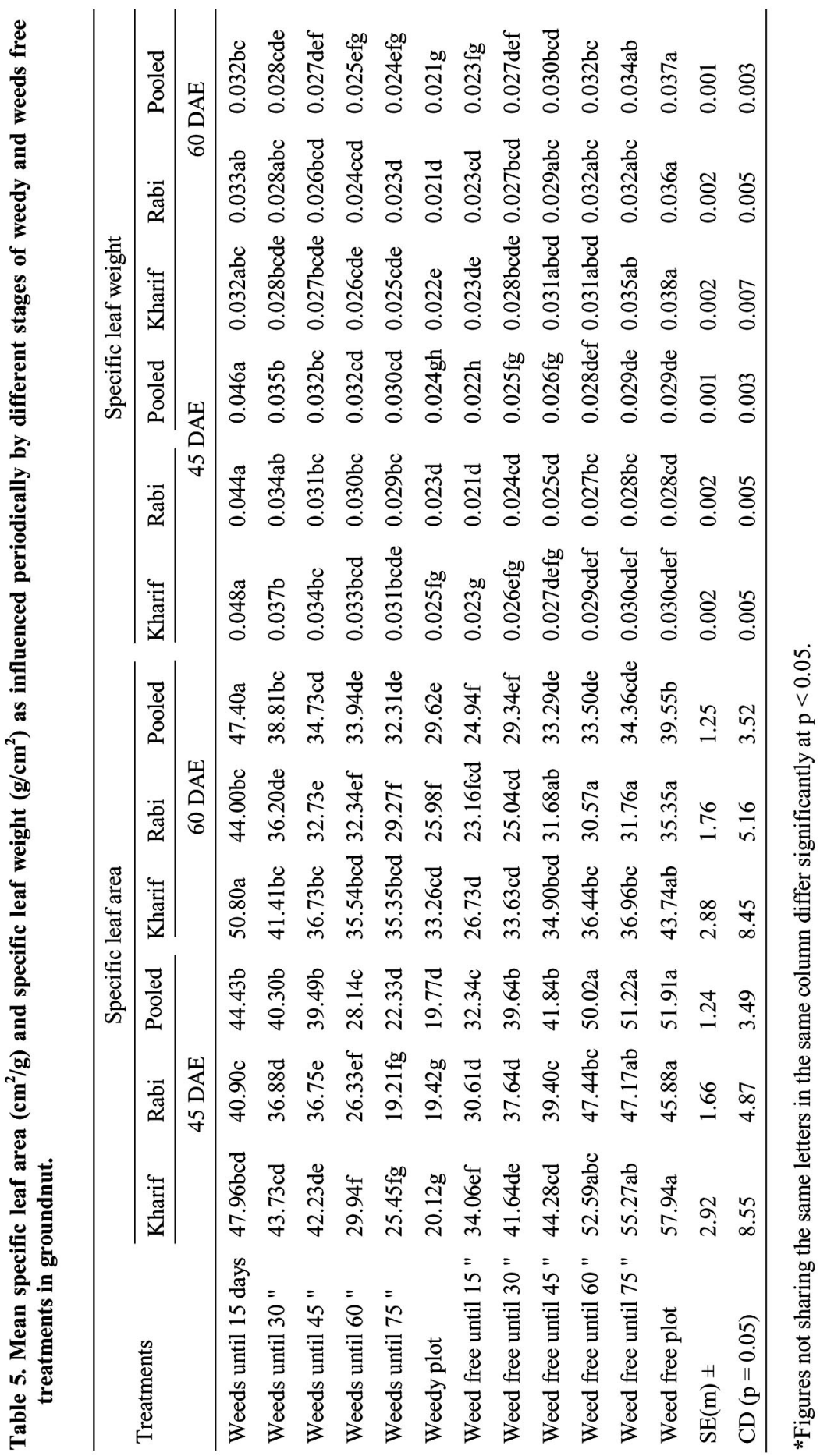




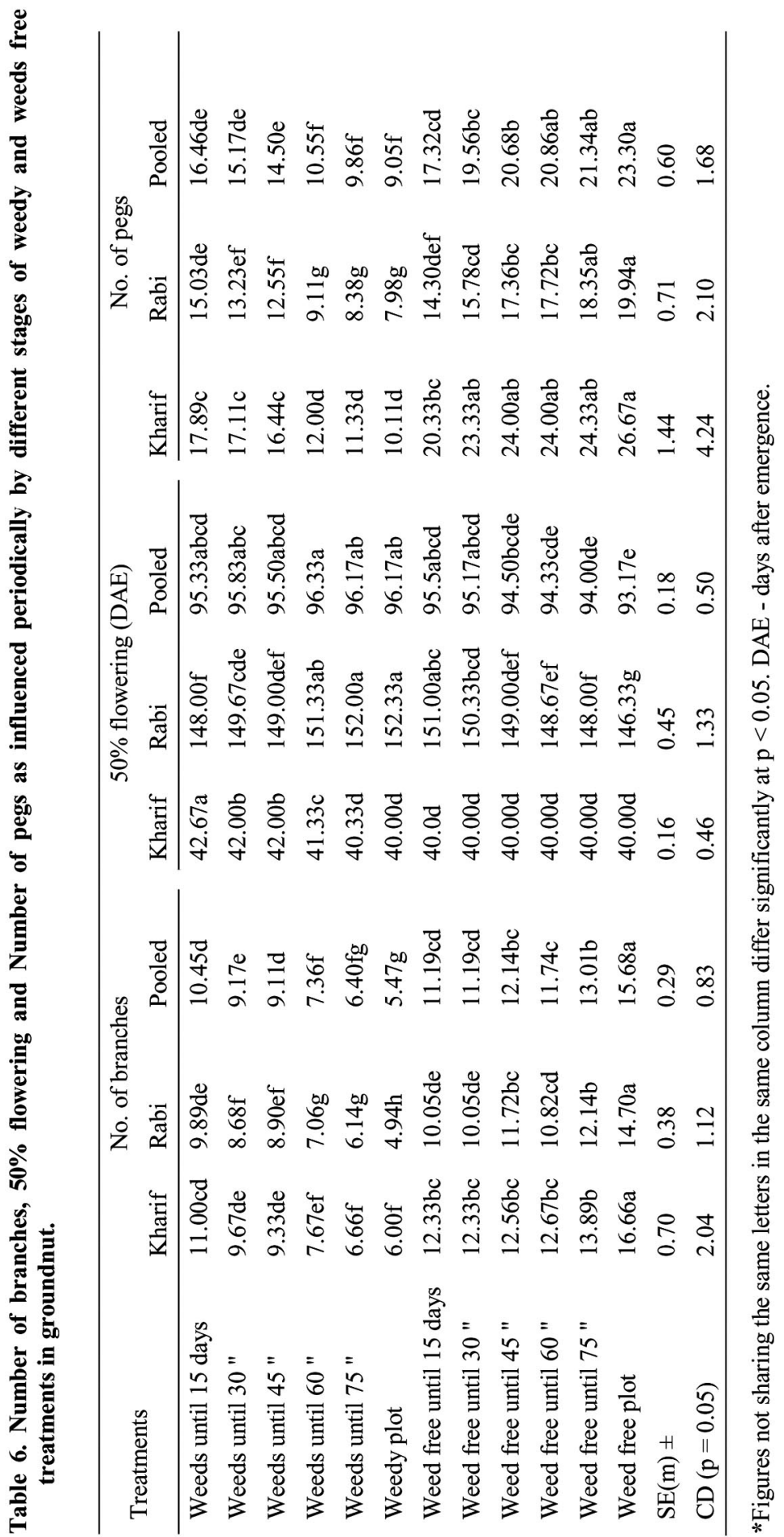


$\mathrm{CO}_{2}$ and light. These resources are very important in canopy development especially $\mathrm{CO}_{2}$ which upon increase in concentration increased these parameters in plant (Kimball and Bindi 2002). Lawson et al., (2002) reported an increase in leaf thickness and also in leaf area under weed infestation. The extra photosynthate, produced by an initial stimulation of $\mathrm{CO}_{2}$ assimilation, is not used primarily to create a larger leaf area (thereby increasing light interception) but seems to be used in the development of thicker leaves, possibly by the accumulation of starch in the chloroplasts (Schapendonk et al. 1989).

Kharif season was getting maximum number of branches as compared to rabi and pooled of experimentation (Table 6). Initial diurnal temperature variation adversely affect on development of branches in rabi groundnut. However, the maximum number of branches was found in weed free up to harvest in both seasons. It might be due to less inter and intra competition for resources (nutrient, space and light) in groundnut.

Table 7. Harvest index and partition efficiency as influenced periodically by different stages of weedy and weeds free treatments in groundnut.

\begin{tabular}{|c|c|c|c|c|c|c|}
\hline \multirow{2}{*}{ Treatments } & \multicolumn{3}{|c|}{ Harvest index $(\%)$} & \multicolumn{3}{|c|}{ Partitioning efficiency $(\%)$} \\
\hline & Kharif & Rabi & Pooled & Kharif & Rabi & Pooled \\
\hline Weeds until 15 days & $48.11 \mathrm{~d}$ & $21.84 \mathrm{~cd}$ & $24.11 b c$ & $61.06 \mathrm{c}$ & $49.72 c$ & $55.39 \mathrm{c}$ \\
\hline Weeds until 30 " & $46.83 \mathrm{e}$ & $22.72 \mathrm{a}$ & $24.81 \mathrm{a}$ & $53.24 \mathrm{e}$ & $43.30 \mathrm{e}$ & $48.27 \mathrm{e}$ \\
\hline Weeds until 45 " & $43.84 \mathrm{~g}$ & $20.76 \mathrm{e}$ & $22.73 \mathrm{e}$ & $56.58 \mathrm{~d}$ & $46.32 d$ & $51.45 \mathrm{~d}$ \\
\hline Weeds until $60 "$ & $44.91 \mathrm{fg}$ & $20.69 \mathrm{e}$ & $22.63 \mathrm{e}$ & $49.09 \mathrm{f}$ & $38.68 \mathrm{~g}$ & $43.89 \mathrm{~g}$ \\
\hline Weeds until 75 " & $41.93 \mathrm{~h}$ & $20.60 \mathrm{e}$ & $22.53 \mathrm{e}$ & $44.23 \mathrm{~h}$ & $34.98 \mathrm{~h}$ & $39.61 \mathrm{i}$ \\
\hline Weedy plot & $51.34 \mathrm{a}$ & $18.94 \mathrm{~g}$ & $21.63 f$ & $42.95 \mathrm{~h}$ & $32.53 \mathrm{i}$ & $37.74 \mathrm{j}$ \\
\hline Weed free until 15 days & $45.52 \mathrm{ef}$ & $20.22 \mathrm{e}$ & $22.30 \mathrm{e}$ & $43.25 \mathrm{~h}$ & $34.76 \mathrm{~h}$ & $39.00 \mathrm{ij}$ \\
\hline Weed free until $30 "$ & $46.48 \mathrm{e}$ & $19.64 f$ & $21.52 \mathrm{f}$ & $64.18 b$ & $51.78 b$ & $57.98 b$ \\
\hline Weed free until $45 "$ & $48.66 \mathrm{~cd}$ & $21.40 \mathrm{~d}$ & $23.55 \mathrm{~d}$ & $62.28 \mathrm{c}$ & $50.85 b c$ & $56.56 c$ \\
\hline Weed free until $60 "$ & $49.50 \mathrm{bc}$ & $22.15 b c$ & $24.20 \mathrm{bc}$ & $50.86 f$ & 41.10f & $45.98 \mathrm{f}$ \\
\hline Weed free until $75 "$ & $49.71 b c$ & $22.40 \mathrm{ab}$ & $24.48 \mathrm{ab}$ & $47.03 \mathrm{~g}$ & $38.03 \mathrm{~g}$ & $42.53 \mathrm{~h}$ \\
\hline Weed free plot & $50.24 \mathrm{ab}$ & $21.84 \mathrm{~cd}$ & $23.86 \mathrm{~cd}$ & $68.35 \mathrm{a}$ & $55.48 \mathrm{a}$ & $61.91 \mathrm{a}$ \\
\hline $\mathrm{SE}(\mathrm{m}) \pm$ & 0.43 & 0.18 & 0.10 & 0.62 & 0.43 & 0.28 \\
\hline $\mathrm{CD}(\mathrm{p}=0.05)$ & 1.27 & 0.51 & 0.28 & 1.81 & 1.26 & 0.78 \\
\hline
\end{tabular}

*Figures not sharing the same letters in the same column differ significantly at $p<0.05$.

In general, Rabi season takes more days to flowering compared to Kharif season individually and in pooled data of the experimentation (Table 6). The amount of cumulative accumulated heat units (GDD) required for groundnut flowering was achieved within short period of time under Kharif season, whereas, in Rabi season it took higher number of days to accumulate same cumulative accumulated heat units (GDD). This might be due to the reason for delayed flowering in Rabi season. It might be due to lower temperature during initial crop growth stage and not able to fulfil the required amount of heat units or other factor required flowering. The maximum number of days to flowering was observed in weed affected plots until 15 DAE in Kharif alone while, Rabi and pooled it was observed under weedy up to harvest. Weed grows faster than the crop and outperforming covers the entire crop canopy quickly and it adversely affects crop 
photosynthetic activity. For getting required amount of heat unit's plants were programmed to increase their respective growth stages like flowering, pegging and their maturity.

Maximum number of pegs/plant in Kharif is followed by pooled than the Rabi season. The highest number of pegs/plant was recorded with different weed free periods than the throughout weedy plots. Among the weedy and weed free plots maximum numbers of pegs formed in weed free check in kharif, rabi and pooled data of experimentation(Table 6).

The mean harvest index (HI) significantly differed in different weedy and weed free treatments kharif season was getting higher $\mathrm{HI}$ than rabi and pooled. Maximum HI was observed in weeds until 15 DAE in kharif, Rabi and pooled data (Table 7).

The partitioning efficiency significantly differed in different weedy and weed free treatments and its values were higher in Kharif season than Rabi and pooled. The higher partitioning efficiency was observed in weed free check in Kharif, Rabi and pooled data of experimentation.

The study revealed that higher value of physiological parameters was found in long weed free treatments and lowest was in long weedy treatment. However, initial weed free treatments getting higher physiological efficiency due to their initial crop growth is slower and weeds are taken/harnessed advantage to utilise all available resources efficiently causing reduced yield and ecological fitness to crop.

\section{References}

Agrow 2003. Agrochemical sales flat in (2002). Agrow: World Crop Protection News. http:/ipm.osu.edu/ trans/043_141. htm. Accessed November 7, 2012.

Appleby AP, Muller F and Carpy S 2000. Weed Control. Muller F, ed. Agrochemicals. New York: Wiley. pp. 687-707.

Arnon DI 1949. Copper enzymes in isolated chloroplast and polyphenol oxidases in Beta vulgaris. Plant Physiol. 24: 1-5.

Banik CN, Nath R and Chakraborty PK 2009. Effect of dates of sowing on growth and yield of groundnut crop. J. Crop and Weed 5(2): 59-62.

Beadle CL 1987. Plant Growth Analysis. Techniques in bio-productivity and photosynthesis, 2nd Ed., pp: 213. Pergamon press, Oxford, New York.

Blackman VH 1919. The compound interest law and plant growth. Annals Botany 33: 353-360.

Fehr WR, Caviness CE, Burmood DT and Pennington JS 1971. Stage of development descriptions for soybeans, (Glycine $\max$ L.). Merr. J. Crop Sci. 11: 929-931.

Gomez KA and AA Gomez 1984. Statistical procedures for agricultural research, 2nd edn. International rice research institute, Los Banos, Philippines. Jon Willey and Sons, New York, pp: 324.

Hakim MdA, Juraimi AS, Musa MH, Ismail MR, Moshiur RMd and Selamat A 2013. Impacts of weed competition on plant characters and the critical period of weed control in rice under saline environment. AJCS., 7(8):1141-1151.

Jat R.S, Meena HN, Singh AL, Surya JN and Misra JB 2011. Weed management in groundnut (Arachis hypogaea L.) in India. Agric. Rev. 32(3): 155-71.

Jayarama Reddy 1995. Integrated weed management using herbicides and cultural practices under two plant densities. M.Sc. (Agri.) Thesis, Agronomy Dept., Univ. Agric. Sci., Bangalore p. 174.

Kimbal BA, Kobayashi K and Bindi M 2002. Responses of agricultural crops to free-air $\mathrm{CO}_{2}$ enrichment. Advances in Agronomy, vol. 77.

Lawson T, Craigon J, Black CR, Colls J, Landon G and Weyers JDB 2002. Potato biology and biotechnology. J. Expt. Bot. 53: 737.

Munene JT, Kinyamario JI, Holst and Mworia JK 2008. Competition between cultivated rice (Oryza sativa) and wild rice (O. punctata) in Kenya. Afr. J. Agric. Res. 3: 605-611. 
Olayinka BU and Etejere EO 2015. Growth analysis and yield of two varieties of groundnut (Arachis hypogaea L.) as influenced by different weed control methods. Ind. J. Plant Physiol. 20(2): 130-136.

Pushp Sharma and Virender S 2012. Effect of growth regulating substances on the chlorophyll, nitrate reductase, leghaemoglobin content and yield in groundnut (Arachis hypogaea), The Bioscan. 7(1): 13-17.

Qiu D, Lin P and Gu SZ 2007. Effects of salinity on leaf characteristics and $\mathrm{CO}_{2} / \mathrm{H}_{2} \mathrm{O}$ exchange of Kandelia candel (L.) Druce seedlings. J. Sci. 53: 13-19.

Schapendonk AHCM, Spitters CT and Groot P 1989. Effects of water stress on photosynthesis and chlorophyll fluorescence offive potato cultivars. Potato Research 32: 17-32.

Senthil Kumar N, Natarajan S, Veeramani A and Senthil Kumar P 2004. Integrated weed control in groundnut (Arachis hypogaea) under varying plant densities. Indian J. Weed Sci. 36(1\&2): 144-145.

Swanton CJ, Nkoa R and Blackshaw RE 2015. Experimental methods for crop-weed competition studies. Weed Sci. 63(sp1): 2-11.

Watson DJ 1947. Comparative physiological studies in the growth of field crops: Variation in net assimilation rate and leaf area between species and varieties, and within and between years. Ann. Bot. 11: 41-76.

(Manuscript received on 22 April, 2018; revised on 15 August, 2019) 